\title{
More on the tobacco menace in India
}

This issue of our journal has three original articles related to tobacco. Each one has a lesson and also raises some controversies.

The one by Goel et al. shows that while the smoking trends in men reduced between 1993 and 2009 in India, the trends in females more than doubled from $1.4 \%$ to $2.9 \%$, during the same period. ${ }^{[1]}$ Does this ring a bell? It is identical to what was seen in the western world several decades earlier. For USA, in 1924 , smoking prevalence in women was $6 \%$. This increased to $16 \%$ by 1929 , became $24 \%$ (for women younger than 40 years) by 1935 and as high as $36 \%$ by the year 1944. In fact, ever smoking peaked among US women in the year 1985, being a staggering $46.2 \% .^{[2]}$

The habit of cigarette smoking in women has followed the trends among men, with a lag of several years. ${ }^{[3]}$ It did so in USA and is now doing the same in India. Moreover it is well-established that the incidence of lung cancer mimics this trend - with a lag of about 7 years. Hence, we should be ready for the increasing incidence of lung cancer in Indian women. ${ }^{[4]}$

Thakur et al. have reported on the prevalence of cigarette smoking and its predictors among school going adolescents in Shimla. ${ }^{[5]}$ They document an incidence of $11.8 \%$ cigarette smoking in school adolescents ( $9^{\text {th }}$ to $12^{\text {th }}$ grade). This study has several flaws. Their definition of cigarette smoking is limited to the 30 days prior to the questionnaire being administered. It also does not include use of tobacco in other forms - and we know that chewing (smokeless) tobacco is very common in India, including in school children. Whereas $32.7 \%$ of men and $1.4 \%$ of women smoke tobacco, many more $36.5 \%$ of men and $8.4 \%$ of women) chew tobacco. ${ }^{[6]}$ The use of smokeless tobacco is also higher among nonsmokers (16-56\% compared with $10-52 \%$ in smokers). ${ }^{[7]}$ Let us not forget that the primary form of tobacco use as far back as in the 1800s was indeed chewing. Also, Thakur's data showing that the smoking incidence was $22 \%$ amongst boys, and $1 \%$ in girls is also misleading - which also reflects on the flaws in the methodology used in this study. Perhaps, it would have been better if they had also focused on measures to prevent and treat the tobacco habit in school adolescents using tested strategies. ${ }^{[8]}$

Reddy et al. studied 410 petrol fillers in Pune area between the age of 17 and 64 years. ${ }^{[9]}$ They found that $242(59 \%)$ used tobacco $-77.68 \%$ were chewing it and $8.26 \%$ were smokers. The overall incidence of tobacco use matches that seen in our country, albeit on the higher side. ${ }^{[6]}$ It is understandable that their profession prevented the people in this report from smoking and hence there is a significantly higher incidence of chewing tobacco. However, the incidence of premalignant lesions reported by them is $68.47 \%$ for leukoplakia, $27.45 \%$

Access this article online Quick Response Code:

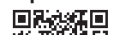

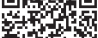

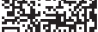

Website: www.sajc.org DOI: 10.4103/2278-330X.142936 for submucous fibrosis and $5.08 \%$ for erythroplakia - higher than reported elsewhere. ${ }^{[9-12]}$ The annual incidence of leukoplakia in the general population varies from $0.2 \%$ to $11 \% .{ }^{[13]}$ Even among tobacco users, the incidence was reported to be $4.5 \%$, rising to $7.1 \%$ when using both forms of tobacco (smoking and chewing). ${ }^{[14]}$ This is also supported by a study in 2017 consecutive patients reporting to a dental college from around Chennai, the highest incidence of leukoplakia reported from those with oral complaints was only $6.82 \%{ }^{[15]}$ Reddy et al., therefore, need to evaluate their data once more to confirm whether their incidence of premalignant lesions is really true.

P. M. Parikh

Department of Medical Oncology, Asian Institute of Oncology, KJ Somaiya Hospital, Sion, Mumbai, Maharashtra, India Correspondence to: P.M. Parikh, E-mail:purvishl@gmail.com

\section{References}

1. Goel S, Tripathy JP, Singh RJ, Lal P. Smoking trends among women in India: Analysis of national representative surveys (1993-2009). South Asian J Cancer 2014;3:200-2.

2. Mills CA, Porter MM. Tobacco-smoking habits in an American city. J Natl Cancer Inst 1953; 13: 1283-97.

3. Novotny TE, Warner KE, Kendrick JS, Remington PL. Smoking by blacks and whites: Socioeconomic and demographic differences. Am J Public Health 1988;78:1187-9.

4. Jemal A, Thun MJ, Ries LA, Howe HL, Weir HK, Center MM, et al. Annual report to the nation on the status of cancer, 1975-2005, featuring trends in lung cancer, tobacco use, and tobacco control. J Natl Cancer Inst 2008; 100:1672-94.

5. Thakur D, Gupta A, Thakur A, Mazta SR, Sharma D. Prevalence of cigarette smoking and its predictors among school going adolescents in North India. South Asian J Cancer 2014;3:193-95.

6. National Family Health Survey (NFHS) - 2005-2006. Use of Tobacco: A Fact Sheet; 2009. Available from: http://www.whoindia.org/LinkFiles/ Tobacco_Free_Initiative_nfhs3pdf. [Last accessed on 2014 Sep 04].

7. Gupta PC. Smokeless tobacco use in India. In: Smoking and Tobacco Control Monograph No. 2. p. 19-26. Available from: http://www. cancercontrol.cancer.gov/brp/tcrb/monographs/2/m2_1.pdf. [Last accessed on 2014 Sep 01].

8. Goenka S, Tewari A, Arora M, Stigler MH, Perry CL, Arnold JP, et al. Process evaluation of a tobacco prevention program in Indian schools - methods, results and lessons learnt. Health Educ Res 2010;25:917-35.

9. Reddy MG, Kakodkar P, Singh A. Tobacco use, body mass index and potentially malignant disorders among petrol fillers in Pimpri-Pune (India): A descriptive study. South Asian J Cancer 2014;3:196-9.

10. Mehta FS, Gupta PC, Daftary DK, Pindborg JJ, Choksi SK. An epidemiologic study of oral cancer and precancerous conditions among 101,761 villagers in Maharashtra, India. Int J Cancer 1972; 10:134-41.

11. Sinor PN, Gupta PC, Murti PR, Bhonsle RB, Daftary DK, Mehta FS, et al. A case-control study of oral submucous fibrosis with special reference to the etiologic role of areca nut. J Oral Pathol Med 1990;19:94-8.

12. Majumder M, Sikdar N, Paul RR, Roy B. Increased risk of oral leukoplakia and cancer among mixed tobacco users carrying XRCC 1 variant haplotype and cancer among smokers carrying two risk genotypes: One on each of two loci, GSTM3 and XRCC 1 (codon 280). Cancer Epidemiol Biomarkers Prev 2005; 14:2106-12.

13. Gupta PC, Mehta FS, Daftary DK, Pindborg JJ, Bhonsle RB, Jalnawalla PN, et al. Incidence rates of oral cancer and natural history of oral precancerous lesions in a 10-year follow-up study of Indian villagers. Community Dent Oral Epidemiol 1980;8:283-333.

14. Mehta FS, Sanjana MK, Shroff BC, Doctor RH. Studies in oral leukoplakia. Indian J Med Res 1961;49:393-9.

15. Saraswathi TR, Ranganathan K, Shanmugam S, Sowmya R, Narasimhan PD, Gunaseelan R. Prevalence of oral lesions in relation to habits: Cross-sectional study in South India. Indian J Dent Res 2006; 17:121-5.

How to cite this article: Parikh PM. More on the tobacco menace in India. South Asian J Cancer 2014;3: 191.

Source of Support: Nil. Conflict of Interest: None declared. 